\title{
Perbandingan Pemberian Heparin Subkutan dan Intravena terhadap Studi Koagulasi dan D-Dimer Pasien dengan Risiko Trombosis Vena Dalam
}

\author{
Sigit Kusdaryono*, Danu Soesilowati**, Himawan Sasongko** \\ *Bagian Anestesiologi dan Terapi Intensif FK Universitas Mataram/ RSUP NTB \\ **Bagian Anestesiologi dan Terapi Intensif FK Undip/ RSUP Dr. Kariadi, Semarang
}

\section{ABSTRACT}

Backgrounds: Thrombosis is the leading cause of death in the United States. About 2 millions of people died every year because of arterial and venous thrombosis. About 80 90\% is for known cause. Thrombosis also cause significant morbidity, one of them is Deep Vein Thrombosis (DVT) that may be followed by pulmonary embolism. Without thromboprophylaxis, the incidence of acquired DVT in hospitals is 10-40\% on all medical and surgical patient, objectively and 40-60\% on major orthopaedics operation.

Objectives: To compare the effectivity of subcutaneous and intravenous heparin prophylaxis dose on D-Dimer, PPT, and aPTT levels in patients with the risk of deep vein thrombosis.

Methods: This is a pre and post test group design study, conducted on 20 patients who have the risk of developing deep vein thrombosis. Blood sample was taken 1 hour after heparin injection, and put into a EDTA containing bottle. Sample sent to laboratorium for examination. Subject divided into two groups by random sampling. Group A received heparin intravenously and group B received heparin subcutaneously. Statistical analysis will be conducted to test the difference between groups using SPSS version 15.

Result : The test resulted in no significant difference in aPTT and PPT between intravenous group and subcutaneous group $(p>0,05)$. Test results in D-Dimer between groups also showed no significant difference $(p>0.05)$

Conclusion : No significant differences produced in PPT, aPTT and D-Dimer levels between intravenously and subcutaneously administered heparin for prevention of deep vein thrombosis.

Keyword : heparin intravenous, heparin subcutaneous, aPTT levels and D-Dimer levels

\section{ABSTRAK}

Latar Belakang: Trombosis di Amerika Serikat adalah penyebab kematian terbanyak. Sekitar 2 juta orang meninggal setiap tahun karena trombosis arteri dan vena. Dengan 80-90\% thrombosis diketahui penyebabnya. Trombosis juga menyebabkan morbiditas yang signifikan, salah satunya adalah trombosis vena dalam (Deep Vein Thrombosis, DVT) yang dapat berlanjut menjadi emboli paru. Tanpa tromboprofilaksis, kejadian DVT nosokomial adalah 10-40\% dari keseluruhan pasien medis dan bedah dan 40-60\% pada pasien pasca bedah ortopedi mayor. 
Tujuan: Untuk membandingkan efektivitas dosis profilaksis heparin subkutan dan intravena terhadap nilai D-Dimer, PPT dan aPTT pada pasien dengan risiko trombosis vena dalam.

Metode: Penelitian ini menggunakan desain kelompok pre dan post test dan dilakukan pada 20 pasien dengan risiko trombosis vena dalam. Sampel darah diambil setelah 1 jam injeksi heparin, kemudian disimpan dalam botol yang mengandung EDTA. Sampel dikirim ke laboratorium untuk pemeriksaan. Subyek dibagi menjadi dua kelompok secara random sampling. Grup A menerima heparin intravena dan kelompok B menerima heparin subkutan. Analisis statistik dilakukan untuk menguji perbedaan antar kelompok dengan SPSS versi 15.

Hasil: Hasil pemeriksaan aPTT dan PPT antara kelompok intravena dan subkutan tidak menunjukkan perbedaan yang signifikan $(p>0,05)$. Hasil pengujian pada D-Dimer intravena dan subkutan juga tidak menunjukkan perbedaan yang signifikan $(p>0,05)$.

Kesimpulan: Tidak ada perbedaan yang signifikan antara pemberian heparin intravena dan subkutan dalam nilai aPTT, PPT dan D-Dimer sebagai pencegahan risiko trombosis vena dalam.

Kata Kunci: heparin intravena, heparin subkutan, aPTT , D-Dimer

\section{PENDAHULUAN}

Trombosis di Amerika Serikat merupakan penyebab kematian terbanyak. Sekitar 2 juta orang meninggal setiap tahunnya baik karena trombosis arteri maupun vena. Sekitar $80-90 \%$ thrombosis dapat diketahui penyebabnya. Lebih dari 50\% pasien tersebut didapatkan trombositopenia atau defisiensi protein koagulasi, baik kongenital atau didapat, yang menyebabkan kejadian trombosis. Trombosis juga menyebabkan morbiditas yang bermakna, salah satunya adalah trombosis vena dalam (Deep Vein Trombosis, DVT) yang berlanjut menjadi emboli paru. Insiden DVT di Amerika Serikat adalah 159 per 100 ribu atau sekitar 398 ribu per tahun. Data mengenai insiden di Asia masih terbatas. ${ }^{1,2}$

DVT merupakan penyakit yang sulit didiagnosis. Kesalahan diagnosis secara klinis mencapai 50\%, karena separuh dari penyakit ini tidak menunjukkan gejala sehingga dapat menyebabkan kematian bila tidak dikenali dan diterapi dengan baik. Tromboemboli akan meningkatkan biaya medis dan peningkatan risiko sindroma stasis vena. Selain itu pencegahan tromboemboli penting kaitannya dengan peningkatan angka ketahanan hidup pada pasien. Pada penelitian Heit's dkk sekitar seperempat pasien dengan tromboemboli vena menderita kematian. Tromboemboli dapat ditegakkan dengan menggunakan gejala dan tanda klinis, akan tetapi sebagian besar tromboemboli vena asimptomatik, oleh karena itu penilaian kejadian tromboemboli vena dengan 
menggunakan skor klinis saja akan sangat meragukan dan diperlukan pemeriksaan tambahan seperti ultrasonografi ataupun venografi. Venografi merupakan baku emas diagnosis tromboemboli, akan tetapi karena sifatnya yang invasif, efek samping dan kesulitannya, maka penggunaan venografi bukan merupakan lini pertama baku diagnostik standar. Ultrasonografi sebagai tindakan non invasif dan mudah dilakukan, merupakan alat bantu diagnostik lini pertama pada penegakan diagnosis tromboemboli vena dan mempunyai sensitifitas dan spesifisitas yang tinggi. ${ }^{2,3}$

Tanpa tromboprofilaksis, insidensi DVT yang diperoleh di rumah sakit secara objektif adalah $10-40 \%$ dari keseluruhan pasien dan 40-60\% pada operasi ortopedik mayor. Dari sekitar 7 juta pasien yang pulang dari 944 rumah sakit di Amerika, tromboemboli vena adalah komplikasi medis kedua terbanyak, penyebab peningkatan lama perawatan dan penambahan biaya pelayanan medis, dan penyebab kematian ketiga terbanyak . Oleh karena hal itulah strategi pencegahannya harus didukung penuh setidaknya berdasarkan stratifikasi risiko sedang sampai tinggi. ${ }^{3,4}$

\section{METODE}

Pemilihan sampel dilakukan dengan consecutive sampling, dimana setiap pasien masuk ICU/HCU yang memenuhi kriteria inklusi dimasukan dalam sampel penelitian sampai jumlah yang diperlukan, dan dibagi menjadi dua kelompok yaitu Kelompok 1 (K1) menggunakan heparin subkutan dengan dosis profilaksis dan Kelompok 2 (K2) menggunakan heparin intravena syringe pump dengan dosis profilaksis

Sampel darah diambil 1 jam setelah heparin diberikan dan disimpan dalam botol EDTA. Sampel segera di kirim ke laboratorium untuk dilakukan pemeriksaan.

Selanjutnya, dilakukan uji normalitas data dan analisis inferensial untuk menguji hipotesis dengan menggunakan uji-T independen apabila data berdistribusi normal dan menggunakan Mann Whitney U test apabila data berdistribusi tidak normal. Analisis statistik menggunakan SPSS for Windows versi 15 .

\section{HASIL}

Telah dilakukan penelitian tentang perbedaan heparin subkutan dan intravena pada 2 kelompok yaitu kelompok $\mathrm{A}=$ intravena dan kelompok $\mathrm{B}=$ subkutan pada masing-masing 10 sampel penderita yang dirawat di ICU setelah memenuhi kriteria inklusi dan eksklusi.

Pada Tabel 2 didapatkan hasil uji pada PPT hari ke-2 dengan PPT hari ke-3 kelompok intravena didapatkan hasil yang berbeda tidak bermakna $p=0,139$ ( $p$ $>0,05)$, pada kelompok subkutan juga didapatkan hasil tidak bermakna $p=0,475$ ( $>0,05)$. Hasil uji pada PPT intravena 
Tabel 1. Karakteristik umum subyek pada masing-masing kelompok

\begin{tabular}{|c|c|c|c|c|c|}
\hline \multirow[t]{2}{*}{ Variabel } & \multicolumn{2}{|c|}{$\begin{array}{c}\text { Intravena } \\
(\mathbf{n}=10)\end{array}$} & \multicolumn{2}{|c|}{$\begin{array}{c}\text { Subcutan } \\
(\mathrm{n}=10)\end{array}$} & \multirow[t]{2}{*}{$\mathbf{p}$} \\
\hline & n & $\%$ & $\mathbf{n}$ & $\%$ & \\
\hline \multicolumn{6}{|l|}{ Umur } \\
\hline $20-29$ & 3 & $15,0 \%$ & 3 & $15,0 \%$ & 0,669 \\
\hline $30-39$ & 0 & $0,0 \%$ & 2 & $10,0 \%$ & \\
\hline $40-49$ & 2 & $10,0 \%$ & 2 & $10,0 \%$ & \\
\hline $50-59$ & 3 & $15,0 \%$ & 2 & $20,0 \%$ & \\
\hline $60-69$ & 1 & $10,0 \%$ & 1 & $5,0 \%$ & \\
\hline$\geq 70$ & 0 & $0,0 \%$ & 0 & $0,0 \%$ & \\
\hline \multicolumn{6}{|l|}{ Jenis kelamin } \\
\hline Laki-laki & 3 & $15,0 \%$ & 3 & $15,0 \%$ & 1,000 \\
\hline Perempuan & 7 & $35,0 \%$ & 7 & $35,0 \%$ & \\
\hline
\end{tabular}

Tabel 2. Hasil rerata uji PPT pada kedua kelompok

\begin{tabular}{cccc}
\hline Kelompok & $\begin{array}{c}\text { Intravena(A) } \\
(\mathbf{n}=\mathbf{1 0})\end{array}$ & $\begin{array}{c}\text { Subcutan(B) } \\
(\mathbf{n}=\mathbf{1 0})\end{array}$ & $\mathbf{p}^{*}$ \\
\hline PPT hari ke 2 & $14,460 \pm 3,349$ & $13,440 \pm 3,071$ & 0,140 \\
PPT hari ke 3 & $12,990 \pm 1,677$ & $14,290 \pm 3,128$ & \\
$\mathbf{p}^{* *}$ & 0,139 & 0,475 & \\
\hline
\end{tabular}

* Indep endent Samplet Test / Mann-Whitney Test, signifikan $p<0,05$

** Paired t Test / Wilcoxon Signed Ranks Test, signifikan $\mathrm{p}<0,05$

Tabel 3. Hasil rerata uji PTT pada kedua kelompok

\begin{tabular}{cccc}
\hline Kelompok & $\begin{array}{c}\text { Intravena(A) } \\
(\mathbf{n}=\mathbf{1 0})\end{array}$ & $\begin{array}{c}\text { Subcutan(B) } \\
(\mathbf{n}=\mathbf{1 0})\end{array}$ & $\mathbf{p}^{*}$ \\
\hline PTT hari ke 2 & $41,400 \pm 30,0247$ & $43,040 \pm 20,0078$ & 0,777 \\
PTT hari ke 3 & $57,020 \pm 47,2030$ & $52,590 \pm 31,7569$ & \\
$\mathbf{p}^{* *}$ & 0,541 & 0,333 & \\
\hline
\end{tabular}

* Independent Sample t Test / Mann-Whitney Test, signifikan $\mathrm{p}<0,05$

** Paired $\mathrm{t}$ Test / Wilcoxon Signed Ranks Test, signifikan $\mathrm{p}<0,05$ 
Tabel 4. Hasil rerata uji DDimer pada kedua kelompok

\begin{tabular}{cccc}
\hline Kelompok & $\begin{array}{c}\text { Intravena(A) } \\
(\mathbf{n}=\mathbf{1 0})\end{array}$ & $\begin{array}{c}\text { Subcutan(B) } \\
(\mathbf{n}=\mathbf{1 0})\end{array}$ & $\mathbf{p}^{*}$ \\
\hline DDimer hari ke 2 & $2885,60 \pm 1423,616$ & $3301,00 \pm 1499,033$ & 0,058 \\
DDimer hari ke 3 & $3152,50 \pm 1688,696$ & $2660,90 \pm 1268,705$ & \\
$\mathbf{p}^{* *}$ & 0,237 & 0,093 & \\
\hline
\end{tabular}

* Independent Sample t Test / Mann-Whitney Test, signifikan $\mathrm{p}<0,05$

** Paired t Test / Wilcoxon Signed Ranks Test, signifikan $p<0,05$

dengan PPT subkutan didapatkan hasil berbeda tidak bermakna $\mathrm{p}=0,140$ $(\mathrm{p}>0,05)$

Pada Tabel 3 didapatkan hasil uji pada PTT hari ke-2 dengan PTT hari ke-3 kelompok intravena didapatkan hasil yang berbeda tidak bermakna $p=0,541$ ( $p>0,05$ ), pada kelompok subkutan juga didapatkan hasil tidak bermakna $\mathrm{p}=0,333(\mathrm{p}>0,05)$. Hasil uji pada PPT intravena dengan PPT subkutan didapatkan hasil tidak bermakna $p=0,777(p>0,05)$

Pada Tabel 4 didapatkan hasil uji pada D -Dimer hari ke-2 dengan D-Dimer hari ke-3 kelompok intravena didapatkan hasil yang berbeda tidak bermakna $\mathrm{p}=0,237 \quad(\mathrm{p}>0,05)$, pada kelompok subkutan juga didapatkan hasil tidak bermakna $p=0,093(p>0,05)$. Hasil uji pada D-Dimer intravena dengan DDimer subkutan didapatkan hasil tidak bermakna $p=0,058(p>0,05)$.

\section{PEMBAHASAN}

Trombus biasanya terbentuk pada daerah dengan aliran darah lambat atau terganggu di sinus vena besar dan kantung ujung katub vena dalam tungkai bawah atau segmen vena yang terpapar oleh trauma langsung. Pembentukan, perkembangan dan disolusi thrombus menggambarkan keseimbangan antara efek rangsangan trombogenik dan berbagai mekanisme protektif. Mayoritas kejadian tromboemboli vena bermula dari deep calf veins, dimana mayoritas trombosis akan menghilang spontan, sekitar 15\% akan berlanjut ke vena proksimal yang menyebabkan sumbatan dan rentan terjadi embolisasi. Bila tidak diterapi, maka trombosis vena yang terjadi di atas lutut, sekitar lebih dari 50\% akan menyebabkan emboli paru. Pemberian antikoagulan seperti heparin baik secara intravena maupun subkutan pada pasienpasien kritis di ICU dapat membantu mencegah terjadinya trombus. ${ }^{2-4}$

Penelitian sebelumnya telah dilakukan untuk mengetahui efek heparin dalam membantu mencegah terjadinya trombus. Terapi dini menunjukkan bahwa 50\% kasus DVT mulai terbentuk pada saat operasi dan $25 \%$ terjadi dalam kurun waktu 72 jam setelah operasi. Oleh karena itu, penting untuk memulai 
profilaksis sebelum dilakukan induksi anestesi pada pasien risiko sedang sampai risiko tinggi. Graduated compression stocking dan pneumatic compression devices dapat dipasang sebelum operasi. Pemberian LowMolecular-Weight Heparin (LMWH) atau Unfractionated Heparin (UFH) juga dapat diberikan sebelum operasi pada pasien risiko tinggi. Adanya peningkatan risiko perdarahan selama operasi tidak banyak terbukti pada beberapa penelitian yang telah dilakukan. $^{5}$

Pada pemberian heparin terhadap pasien dengan risiko terhadap terjadinya trombosis vena dalam, pada pemeriksaan laboratorium akan didapatkan pemanjangan waktu pembekuan darah. $^{5}$

Menurut penelitian Elizabeth dkk, terdapat pemanjangan waktu pembekuan darah pada pemberian heparin baik secara subkutan maupun intravena, keduanya berbeda tidak bermakna, hal tersebut sesuai dengan hasil uji PPT subkutan dibanding intravena tidak bermakna $p=0,140(p>0,05)$. Heparin diserap dengan baik pada pemberian subkutan, hanya onset yang diperlukan lebih lama dibandingkan intravena ${ }^{5,6}$

Gottfried dan Adachi, menyatakan bahwa APTT juga mengalami pemanjangan pada pemberian heparin, baik subkutan maupun intravena berbeda tidak bermakna. Dari hasil uji APTT secara subkutan dan intravena didapatkan hasil berbeda tidak bermakna $p=0,777(p>0,05)$, hal ini disebabkan heparin di metabolism sempurna pada pemberian subkutan maupun intravena $^{5,6,7}$

Penelitian Burns dkk, menyatakan terdapat penurunan jumlah D-Dimer dalam darah pada pemberian heparin baik secara subkutan maupun intravena, dan tidak ada perbedaan yang bermakna pada kedua cara pemberian. Pada uji DDimer pada pemberian heparin subkutan dan intravena didapatkan hasil berbeda tidak bermakna $\mathrm{p}=0,058(\mathrm{p}>0,05)$. Hal ini disebabkan karena heparin juga diabsorbsi dengan baik pada pemberian subkutan. ${ }^{5,9}$

Menurut penelitian Prandoni dkk, terdapat penurunan jumlah fibrinogen setelah pemberian heparin, dan tidak terdapat perbedaan hasil pada pemberian heparin secara subkutan dan intravena hal ini sesuai dengan hasil uji fibrinogen pada pemberian heparin subkutan dan intravena $p=0,258 \quad(p>0,05)$. Hal ini disebabkan pemberian heparin subkutan yang banyak mengandung lemak menyebabkan heparin diserap dengan baik, oleh karena heparin larut dalam lemak. ${ }^{5,10,11}$

Berdasarkan hasil di atas pemberian heparin melalui jalur subkutan maupun intravena untuk mengatasi risiko terjadinya DVT, karena keduanya memiliki daya terapis yang relatif sama.

\section{KESIMPULAN}

Didapatkan perbedaan yang tidak bermakna pada pemberian heparin 
secara subkutan dibandingkan secara intravena terhadap pencegahan factor risiko deep vein thrombosis. Penggunaan heparin pada pasien-pasien critical ill sebagai tromboprofilaksis deep vein thrombosis dapat diberikan baik melalui jalur intravena maupun subkutan.

\section{DAFTAR PUSTAKA}

1. Geerts WH, Pineo GF, Heit JA, Bergqvist D, Lassen MR, Colwell CW, et al. Prevention of venous thromboembolism: the Seventh ACCP Conference on Antithrombotic and Thrombolytic Therapy. Chest 2004 (Sep);126(3 Suppl):338S-400S.

2. Geerts WH, Heit JA, Clagett GP, Pineo GF, Colwell CW, Anderson Jr FA, et al. Prevention of venous thromboembolism. Chest 2001 (Jan);119(1Suppl):132S-75S.

3. Heit JA, Silverstein MD, Mohr DN, Petterson TM, O'Fallon WM, Melton III LJ. Risk factors for deep vein thrombosis and pulmonary embolism: a population-based casecontrol study. Arch Intern Med 2000 (Mar 27);160(6):809-15.

4. Levitan N, Dowlati A, Remick SC, Tahsildar HI, Sivinski LD, Beyth R, et al. Rates of initial and recurrent thromboembolic disease among patients with malignancy versus those without malignancy. Risk analy- sis using Medicare claims data. Medicine (Baltimore) 1999 (Sep);78(5):285-91.

5. Morgan MA, Iyengar TD, Napiorkowski BE, Rubin SC, Mikuta JJ. The clinical course of deep vein thrombosis in patients with gynecologic cancer. Gynecol Oncol 2002 (Jan);84(1):67-71.

6. Elizabeth M. Van Cott, M.D., and Michael Laposata, M.D., Ph.D., Coagulation. In: Jacobs DS et al, ed. The Laboratory Test Handbook, 5th Edition. Lexi-Comp, Cleveland, 2001; 327-358.

7. Gottfried EL and Adachi MM, Prothrombin Time and Activated Partial Thromboplastin Time Can Be Performed on the First Tube, $A m$ J Clin Pathol, 1997, 107(6):681-3.

8. Andrew M, Paes B, and Johnston M, Development of the Hemostatic System in the Neonate and Young Infant,Am J Pediatr Hematol Oncol, 1990, 12(1)95-104.

9. Burns ER, Goldberg SN, and Wenz B, Paradoxic Effect of Multiple Mild Coagulation Factor Deficiencies on the Prothrombin Time and Activated Partial Thromboplastin Time,.Am J Clin Pathol, 1993, 100(2):94-8.

10. Prandoni P, Bagatella P, Bernardi E, et al, Use of an Algorithm for Administering Subcutaneous Heparin in the Treatment of Deep Venous Thrombosis,Ann Intern Med, 1998, 129(4):299-302.

11. Kearon C, Harrison L, Crowther M, et al, Optimal Dosing of Subcutaneous Unfractionated Heparin for the Treatment of Deep Vein Thrombosis,Thromb Res, 2000, 97(6):395403. 